\title{
New post saves science and society course at Stanford
}

Washington. The Science, Technology and Society (STS) programme at Stanford University, under threat earlier this year when the School of Engineering was unable to find a tenured faculty member to run it (see Nature 381, 183; 1996), appears likely to be saved following a decision by the university to create a new tenured position.

The move will ensure the continued availability of degrees majoring in STS at Stanford, although responsibility for the popular undergraduate programme will move from the School of Engineering to the School of Humanities and Sciences.

Three social science departments - economics, political science and sociology have each been asked to put forward a ranked shortlist of candidates for the new position. The successful applicant will have tenure in one of these departments, and will also chair the interdisciplinary STS programme.

University officials say that much of the programme's recent problems stemmed from the difficulty of persuading senior department staff to spend up to half their time running an interdisciplinary programme within an incentive structure that chiefly rewards activities inside their own departments.

The university senate agreed to make the extra tenured position available after protests from students, who argued that the programme was important in building links between engineering, science and social science at the university.

Stephen Haber, associate dean for social science in the School of Humanities and Sciences, says: "There is wide recognition that STS is an important programme. The issue has been who should direct it." Haber adds that the three departments will compile shortlists of applicants by 1 November, and that he hopes to appoint "a senior scholar from within the discipline" of STS before the end of this academic year.

But Robert McGinn, a non-tenured professor who currently runs the programme in the School of Engineering, says that the university will not enrol new students majoring in STS until the appointment is filled. He says that the departments will face "a tricky situation" in filling the slot, since they will be accepting someone for a rare tenured position in their own departments whose main interest will lie outside, in the interdisciplinary programme.

McGinn also expresses concern that the programme will lose its traditional emphasis on the impact of technology, and therefore its relevance to engineering students.

But Haber promises that the programme "can maintain its emphasis on technology and society". He says that a significant proportion of the teaching is already taking place in the School of Humanities and Sciences, and he hopes that people from the engineering school will continue to play an important role when the directorship is moved.

\section{Demonstrators call on Yeltsin to honour his budget pledge}

Moscow. Labour unions representing Russian scientists staged demonstrations in several cities last week demanding full and immediate payment of government funds promised in the 1996 science budget, 30 per cent of which remains unpaid.

Around 2,000 scientists gathered in Triumph Square in Moscow, urging the government to honour its pledge, signed by President Boris Yeltsin, to reserve 4 per cent of government spending for science. Demonstrations were also held in the cities of St Petersburg, Novosibirsk, Ekaterinburg, Nizhniy Novgorod and other places that host Russia's science establishments.

The demonstrators were joined by Vladimir Strakhov, 64, director of the Earth Physics Institute of the Russian Academy of Sciences, of which he is a senior member. Strakhov has been on hunger strike since the end of September with Igor NaumenkoBondarenko, chairman of the institute's trade union committee. Both claim that the government's cavalier treatment of Russian science is causing irreparable damage.

Strakhov says 30 of the Earth physics institute's 900 employees have left the country. "The departure of only ten such members will cause a loss on a national scale," he adds. What he describes as "mafia capitalism" is "crunching the bones of Russian science". Strakhov says that science "has reached its death throes" but the government either has not noticed or has decided to ignore the situation.

But Strakhov is a lone voice in the upper echelons of the Russian Academy of Sciences. A recent meeting of the academy's presidium, also attended by directors of the academy's institutes, concluded that, under the country's present economic circumstances, it was "sinful" for academy members to complain, particularly as other state employees, such as teachers and other 'cultural workers' had received only 40 per cent of funds allocated in their budgets.

The academy praised the government for cancelling debts incurred by its institutes, giving these priority over social expenditure. It also welcomed the government's decision to find an additional 80 billion roubles (US\$14.7 million) to cover its debts to scientists, and to promise to increase this sum by two and a half times by the end of the year.

The presidium declined to make additional demands on the government, on the grounds that the state had done what it could for science. But Strakhov and his supporters remain angry. Strakhov complains about "the criminal pittance awarded to the overwhelming majority of scholars. He says he is determined to launch a Russian-wide strike next month.

Carl Levitin 